\title{
Pengaruh Prestise Merek dan Kepercayaan Merek terhadap Harga Premium: Peran Cinta Merek sebagai Variabel Pemoderasi
}

\author{
Aditya Pandowo \\ Universitas Negeri Manado \\ e-mail: aditya.pandowo@unima.ac.id
}

\begin{abstract}
The research objective is to explore the influence of brand prestige and brand trust on brand love and premium prices. Customers holding prestigious brands are trusted that the brand will enhance their values. Furthermore, when they trust the brand, they become dependent and love the brand all the time. When customers like a brand, they want to buy a brand even at a high cost. 165 participants were taken by purposive sampling method. Respondents are young hedonist audiences in premium cinema. Moderated Regression Analysis is used to test the relationships between constructs. The results show that brand prestige can predict brand love and premium prices significantly. In addition, brand trust has an impact on brand love and premium prices but not significantly. The same thing is found in the relationship between brand love and premium prices. Another finding is the role of pure moderation of brand love.
\end{abstract}

\section{Keyword: Brand Prestige, Brand Trust, Brand Love, Premium Price}

\section{PENDAHULUAN}

Salah satu tantangan bagi pemasar dalam dunia usaha saat ini adalah mengikat konsumen dan menjadikan mereka sebagai konsumen jangka panjang. Konsumen yang cinta terhadap suatu merek akan mendorong mereka untuk membeli merek yang bersangkutan. Didorong oleh hasrat yang mendominasi pikiran, perasaan, dan tindakan (Belk, Ger and Askegaard, 2003) sehingga hasil positif akan membawa pada perilaku pembelian berkelanjutan dan tetap. Tahap selanjutnya akan tercipta hubungan relasional konsumen dan merek.

Prestise merek merupakan salah satu alasan dasar keinginan konsumen untuk membeli suatu merek. Prestise merek dipandang sebagai alat atau media untuk menunjukkan status sosial dan kesejahteraan (Dubois and Czellar, 2002), pemborosan, dan kualitas produk yang superior. Semakin mahal dan mewah suatu merek, semakin tinggi prestise yang didapatkan. Bagi beberapa konsumen, prestise merek berasosiasi dengan kualitas, kemewahan (Hwang and Han, 2014), dan eksklusivitas (Pandowo, 2017).

Disisi lain, merek dengan profil yang tinggi lebih mudah menimbulkan kepercayaan pada merek itu sendiri (Jin, Line and Merkebu, 2016). Kombinasi biaya, segmen tinggi, fitur terkini, dan durabilitas yang panjang menjadi daya tarik merek. Merek yang populer, pengalaman positif, dan reputasi yang baik juga dapat mendorong kepercayaan merek. Oleh karena itu, kepercayaan merek merupakan faktor penting baik bagi konsumen hedonis maupun konsumen utiltarian (Hanzaee and Andervazh, 2012). 
Layanan berkelas yang ditawarkan oleh sinema bagi penonton kelas satu menjadi pembeda dengan layanan bagi penonton regular. Penonton dimanjakan dengan fasilitas eksklusif dalam ruangan seperti dolby surround system, tempat tidur (velvet) atau reclining seat (premiere \& gold class), dan loket antrian yang nyaman. Selain itu, pengantaran makanan dalam ruangan juga dilayani oleh pegawai dan lounge ruang tunggu yang nyaman dengan makanan ringan gratis (CGV). Konsep layanan ini tentu saja memberikan prestise tersendiri bagi pemegang tiket premium meskipun harus mengorbankan lebih banyak biaya dibandingkan dengan kelas reguler. Simbiosis mutualisme yang berlaku dan menguntungkan kedua pihak.

Konsumen usia muda adalah kelompok konsumen dengan hasrat yang tinggi dalam mencoba hal-hal baru dibanding kelompok konsumen lainnya. Apalagi kelompok ini juga mencari jati diri dan penerimaan status dari rekan dan masyarakat sosial melalui kemampuan membeli sebagai bagian dalam mengekspresikan selera, menghargai diri sendiri, dan kebanggaan atas diri sendiri. Bagi konsumen usia muda, saat menyadari dan melihat suatu merek prestisius, pembelian emotional dan hedonis lebih besar dari pembelian rasional yang berlandaskan utilitarian. Dalam perspektif mereka, pembelian hedonis bersifat subyektif dan personal (Kazakeviciute and Banyte, 2012). Oleh karena itu,merek yang prestisius dianggap sebagai jalan masuk untuk diterima oleh komunitas. Merek dengan reputasi yang tinggi akan lebih mudah dipercaya oleh konsumen. Kombinasi prestise dan kepercayaan akan meningkatkan hasrat konsumen untuk mencintai merek tersebut.

Oleh karena itu, memperkuat cinta merek bagi konsumen usia muda menjadi tantangan bagi pemasar. Penelitian terdahulu telah mengeksplorasi peran prestise merek, kepercayaan merek, maupun maupun cinta merek (Albert, Merunka, and Valette, 2008; Carroll and Ahuvia, 2006). Meski demikian, belum ada yang menyentuh industri sinema maupun konsumen usia muda. Hasil penelitian diharapkan dapat memberikan kontribusi baik bagi akedemisi terutama dunia manajemen pemasaran serta aplikasi konstruk dalam operasional industri. Tujuan dari penelitian ini adalah untuk menginvestigasi anteseden dari cinta merek dan efeknya terhadap perilaku pembelian kembali.

Tulisan ini dimulai dengan kerangka teori anteseden dari cinta merek dan impak yang dihasilkan. Kemudian, penjabaran metodologi dan instrumen yang digunakan dalam penelitian ini. Selanjutnya, penyajian analisis statistik dan intepretasi hasil penelitian. Terakhir, simpulan dan keterbatasan penelitian dan saran bagi penelitian dimasa depan.

\section{TINJAUAN PUSTAKA}

\section{Prestise Merek (Brand Prestige)}

Prestise merek didefinisikan sebagai level produk yang berhubungan dengan merek (Steenkamp, Batra and Alden, 2003) dimana konsumen menghubungkan merek tersebut dengan dirinya untuk meningkatkan kepercayaan diri (Bizman and Yinon, 2002). Pada hakekatnya, prestise menjadi simbol penting dalam meningkatkan status sosial. Merek yang prestisius dapat dilihat dari keunikan, capaian istimewa yang menjadi fitur unggulan dari merek tersebut yang dikombinasikan 
dengan kemewahan yang berhubungan dengan kenyamanan, keindahan, dan kesempurnaan (Dubois and Czellar, 2002), interaksi yang ada antara keduanya, atribut-atribut produk, dan nilai simbolik (Vigneron and Johnson, 1999). Prestise merek pada ujungnya akan mendorong antusiasme dan hasrat konsumen (Belk, 2004), dan meningkatkan nilai konsumen yang diperoleh dari pengakuan status dan peran (Kwak and Sojka, 2010).

Beberapa penelitian menunjukkan prestise merek dibentuk oleh pengalaman merek dan kepribadian merek (Erdoğmuş and Büdeyri, 2012), kesempurnaan merek (Prince and Davies, 2009), kualitas dan kinerja merek (Dubois and Czellar, 2002), harga premium (Truong, McColl and Kitchen, 2009), dan pengaruh dari kelompok referen (Bearden and Etzel, 1982). Disisi lain, prestise merek juga menjadi prediktor yang singifikan bagi kepuasan konsumen, kepercayaan merek, loyalitas merek, dan intensitas pembelian (Steenkamp et al., 2003), persepsi kualitas (Erdoğmuş and Büdeyri, 2012), dan hasrat merek (Belk, 2004). Saat konsumen memandang suatu merek prestisius, maka keinginan untuk membeli muncul dan meyakini kemampuanmerek untuk meningkatkan status sosial dan memperbaiki cara pandang komunitas terhadap mereka. Prestise merek dipandang sebagai representasi identitas dan kepribadian konsumen.

Jika konsumen memandang suatu merek dapat meningkatkan prestise dan status (Mazzarol, Sweeney and Soutar, 2007), konsumen cenderung bertahan dan mengandalkan merek tersebut. Hal ini dikarenakan prestise merek merujuk pada kemampuan finansial dan tingkat kesejahteraan seseorang (Vigneron and Johnson, 1999). Bagi konsumen, prestise merek akan memberikan pengakuan status dari rekan, kerabat, maupun komunitas, dan menunjukkan perannya dalam komunitas (Kwak and Sojka, 2010). Prestise merek juga menunjukkan kepercayaan mereka terhadap merek untuk mampu menunjukkan kinerja sesuai harapan mereka. Hal ini juga berarti konsumen mempersepsikan merek yang berkelas dan prestisius berujung pada kecintaan konsumen pada merek.

Selanjutnya, harga yang tinggi biasanya melekat pada merek yang prestisius. Prestise inilah yang mendorong konsumen untuk tetap membeli meski dengan harga yang lebih tinggi (Carlson, Donavan and Cumiskey, 2009). Menurut mereka, keputusan pembelian merek prestisius lebih menekankan pada faktor emosional dibandingkan faktor rasional. Tantangan bagi pemasar adalah menarik konsumen untuk tetap setia pada merek meskipun dibebankan dengan harga yang lebih mahal. Hal ini disebabkan karena merek yang prestisius lebih agresif dalam penentuan harga dibanding merek non prestisius (Truong, McColl and Kitchen, 2009). Bagi konsumen hedonis, harga yang mahal harus sebanding dengan nilai yang diperoleh. Mereka ingin diperlakukan spesial karena sudah mengeluarkan pengorbanan lebih besar (Phau and Prendergast, 2000). Meski demikian, kerelaan konsumen untuk mengeluarkan pengorbanan lebih besar asalkan mendapatkan merek yang prestisius adalah bagian dari sifat alamiah manusia. Dengan kata lain, prestise yang tinggi akan membawa dampak pada harga yang tinggi pula. 


\section{Kepercayaan Merek (Brand Trust)}

Kepercayaan merek berhubungan dengan harapan konsumen pada kehandalan merek bahkan pada situasi terburuk sekalipun (Delgado and Munuera, 2001) untuk menghindari ketidakpastian, dan meningkatkan kenyamanan konsumen (Chiu, Huang and Yen, 2010). Kepercayaan merupakan elemen dinamis yang dapat bersifat unidimensional (Morgan and Hunt, 1994), bidimensional (Ganesan, 1994), tridimensional (Hess et al., 2014). Kepercayaan merek terdiri kecukupan, filantropi, dan kejujuran sebagai indikator (Suh and Han, 2003).

Penelitian sebelumnya menunjukkan interaksi berulang sebagai kunci dalam membangun kepercayaan merek (Schau, Muñiz and Arnould, 2009). Selain itu, beberapa konstruk juga memberikan pengaruh signifikan bagi kepercayaan merek antara lain, pengalaman merek dankepuasan merek (Chinomona, 2013), persepsi kualitas (Erciş et al., 2012), dan kepribadian merek (Louis and Lombart, 2010).

Dalam kapasitasnya sebagai prediktor, kepercayaan merek memberikan dampak pada hasrat merek (Albert and Merunka, 2013). Merek yang dapat dipercaya membuat konsumen tidak ingin berpindah. Ketergantungan dan kepercayaan pada merek yang bersangkutan akan menyebabkan konsumen semakin mencintai merek tersebut. Pembuktian sebelumnya melalui study yang dilakukan oleh Yasin and Shamim, (2013) menunjukkan adanya signifikansi pengaruh kepercayaan merek terhadap cinta merek.

Konsumen memilih merek yang dapat dipercaya bukan hanya karena dapat memberikan kualitas dan layanan, tapi juga memberikan tambahan nilai bagi pemakainya. Semakin tinggi kepercayaan konsumen pada suatu merek, semakin besar kemungkinan untuk tetap menggunakannnya. Albert and Merunka, (2013) menemukan dua dari tiga dimensi kepercayaan merek secara signifikan menjadi predictor bagi cinta merek, yaitu kehandalan dan kejujuran. Pada perilaku konsumen hedonis, pengguna merek yang dipercaya akan tetap membeli meskipun ditawarkan pada harga tinggi. Hal ini dikarenakan fokus pembelian bukan pada manfaat yang diperoleh akan tetapi pada nilai yang ditawarkan.

\section{Cinta Merek (Brand Love)}

Cinta merek didefinisikan sebagai hubungan emosional (Carroll and Ahuvia, 2006) yang bersifat jangka panjang antara konsumen dan merek (Fournier, 1998) sebagai refleksi ikatan yang mendalam antara kedua pihak. Fungsi dari cinta merek adalah memperkuat relasi antar konsumen dan merek serta menurunkan kemungkinan perpindahan akibat ketidakpuasan.

Cinta merek diklasifikasikan berbeda dengan kepuasan. Konsumen yang berbeda bisa saja mendapatkan kepuasan dari merek yang sama. Namun intensitas dan kecenderungan mempertahankan relasi dalam jangka panjang yang membedakan keduanya (Carroll and Ahuvia, 2006). Secara singkat, perbedaaan disebabkan karena cinta merek bersifat afektif. 
Dalam perkembengannya, dinamika dimensi cinta merek terus berevolusi. Thomson, MacInnis and Park, (2005) mengklasifikasi cinta merek dalam tiga dimensi: hasrat (passion), kasih (affection), dan relasi (connection). Albert, Merunka, and Valette, (2008) kemudian membagi cinta merek kedalam 2 dimensi: idealisasi (idealization), keintiman (intimacy), kesenangan (pleasure), mimpi (dream), kenangan (memories), dan keunikan (uniqueness); dan hasrat (passion), kasih (affection). Menurut mereka, beberapa karakteristik konsumen yang cinta merek adalah: (1) berhasrat pada merek, (2) terikat dengan merek, (3) evaluasi positif pada merek, (4) respon emosional yang positif, dan (5) mendeklarasikan kecintaan pada merek.

Berdasarkan karakterisitk diatas, konsumen yang mencintai merek akan selalu bertindak positif dengan melanjutkan usahanya untuk mendapatkan benefit dari merek tersebut (Aaker, 1991). Mereka menilai hubungan mereka dengan merek secara emosional positif (Albert and Merunka, 2013). Kecintaan akan merek membuat merek tersebut tidak tergantikan. Meskipun merek lain menawarkan harga yang lebih murah, konsumen dengan rasa cinta merek yang tinggi tetap akan berusaha untuk mendapatkan merek tersebut. Rasa cinta yang tinggi membuat konsumen rela berorban meski dengan harga yang lebih tinggi untuk mendapatkan merek tersebut. Dalam perspektif mereka, kehilangan merek akan mengakibatkan pengorbanan yang lebih besar sehingga membawa kegelisahan dan kesulitan (Thomson et al., 2005). Tingkat keikhlasan seorang konsumen untuk berkorban dengan harga tinggi bergantung pada seberapa dalam kecintaannya pada sebuah merek. Penelitian sebelumnya telah mengkonfirmasi hubungan positif antara cinta merek dan harga premium secara signifikan (Rodrigues and Reis, 2013)

\section{Harga Premium (Premium Price)}

Harga premium telah diakui sebagai kunci sukses sebuah merek (Netemeyer et al., 2004). Harga premium dikondisikan ketika konsumen memilih untuk mengorbankan biaya yang lebih besar daripada membayar untuk produk atau layanan merek saingan (Aaker, 1996). Harga premium terdiri dari kualitas tinggi plus tidak berwujud gaya, keunikan, kesempatan, dan pengalaman (Allsopp, 2005).

Konsumen sering melihat harga premium sebagai indikator jaminan, indikasi pribadi dan sosial (Belén, Vázquez and Iglesias, 2001). Ini menggambarkan harga maksimum yang bersedia dibayar oleh pembeli dengan imbalan sejumlah barang atau jasa tertentu .

Penelitian sebelumnya telah menunjukkan beberapa konstruksi terkait dengan harga premium. Identifikasi merek, kepuasan merek, dan loyalitas merek termasuk yang dapat memprediksi munculnya keinginan untuk membayar dengan harga premium (Sutikno, 2011), citra merek (Sharma and Patterson, 2000); pilihan merek (Pritchard, Havitz and Howard, 1999); kualitas, dan nilai (Molinari, Abratt and Dion, 2008) 


\section{Kerangka Pemikiran}

Dengan demikian kerangka pemikiran pengaruh prestise merek dan kepercayaan merek terhadap harga premium: peran cinta merek sebagai variabel pemoderasidigambarkan sebagai berikut:

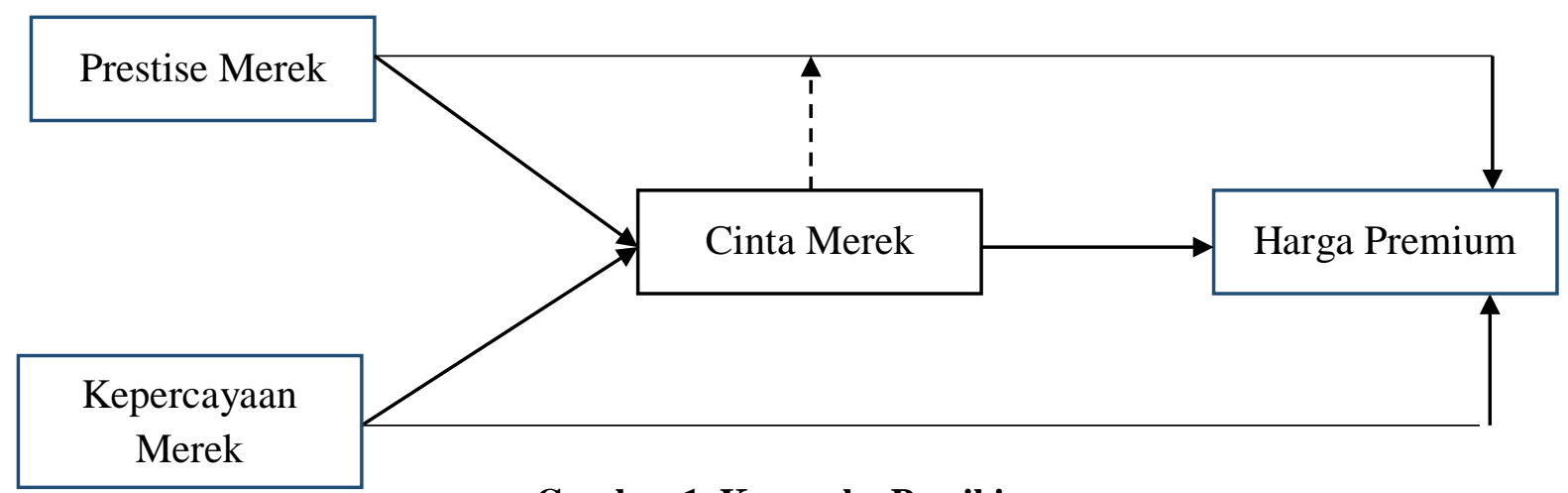

Gambar 1. Kerangka Pemikiran

\section{Hipotesis Penelitian}

$\mathrm{Ha}_{1}$ : Semakin tinggi prestise merek, semakin besar kecintaan pada merek.

$\mathrm{Ha}_{2}$ : Semakin tinggi prestise merek, semakin besar kemungkinan membeli dengan harga premium.

$\mathrm{Ha}_{3}$ : Semakin tinggi kepercayaan konsumen pada merek, semakin besar kecintaan pada merek.

$\mathrm{Ha}_{4}$ : Semakin tinggi seseorang mempercayai merek, semakin besar kemungkinan membeli dengan harga premium

$\mathrm{Ha}_{5}$ : Semakin tinggi kecintaan konsumen pada merek, semakin besar kemungkinan melakukan pembelian meski pada harga tinggi

\section{METODE PENELITIAN}

\section{Populasi dan Sampel Penelitian}

Penelitian ini berbentuk deskriptif dengan menggunakan metode survey untuk mengumpulkan data. Data yang terkumpul bersifat cross-sectional baik dalam rentang waktu maupun jenis data. Data dikumpulkan dengan menggunakan metode purposive sampling. Kriteria dalam penelitian ini adalah konsumen muda usia yang menggunakan layanan sinema premium selang 6 bulan terakhir. Sejumlah minimal 85 orang responden dipilih dan layak sebagai responden berdasarkan kriteria yang sudah ditetapkan.

Kuesioner disusun berisika sejumlah parameter mengenai konstruk yang diteliti dalam penelitian ini yaitu: prestise merek, kepercayaan merek, cinta merek, dan harga premium. Seluruh parameter diukur dengan menggunakan 7- point Likert like scale dengan interval 1 mewakili "sangat tidak setuju sekali” hingga 7 sebagai "sangat setuju sekali”. Kuesioner dibagi dalam dua bagian, 
bagian pertama berisikan informasi mengenai demografi responden, seperti usia, gender, dan frekuensi pembelian, dan sinema pilihan. Bagian kedua berisikan parameter pengujian model penelitian.

Instrumen pengujian untuk mengukur prestise merek diadopsi dari (Steenkamp et al., 2003) sejumlah 4 item parameter. 4 item instrument untuk mengukur kepercayaan merek berasal dari (Chaudhuri and Holbrook, 2001). 6 item instrument cinta merek diadaptasi dari (Albert et al., 2008). Terakhir, 3 item parameter harga premium berasal dari (Rodrigues and Reis, 2013).

Langkah pertama adalah mendeskripsikan responden kedalam tiga bagian, usia, gender, dan frekuensi pembelian, dan sinema pilihan. Kemudian, pengujian validitas dan reliabilitas untuk mengeliminasi kelayakan dan kehandalan parameter dalam mengukur konstruk. Selanjutnya, pengujian hipotesis dan diskusi hasil penelitian. Pada bagian akhir, simpulan, implikasi manajerial, dan arahan untuk penelitian berikutnya di bagian terakhir.

Pengujian validitas dan reliabilitas diukur sebelum pengujian hipotesis dilakukan. Tujuan dari pengujian validitas untuk menguji sejauh mana indicator dapat mengukur konstruk sementara pengujian reliabilitas dimaksudkan untuk mengukur konsistensi parameter dalam mengukur konstruk. Suatu indicator dikatakan valid jika melewati batas minimal 0.4 sedangkan nilai minimal Cronbach alpha untuk reliabilitas adalah 0.6. Sebelum hipotesis diuji, pengukuran data menggunakan pengujian moderated regression analysis untuk melihat hubungan antar variabel. Untuk memastikan model telah memenuhi kriteria BLUE (Best Linear Unbiased Estimator), maka pengujian asumsi klasik perlu dilakukan dengan cara menguji normalitas, multikolinearitas, dan heterokedasitis. Sebagai tambahan, pengujian koefisien korelasi dan koefisien determinasi dilakukan sebelum analisa regresi.Pengujian hipotesa menggunakan uji t untuk mengukur seberapa besar kebenaran atas hipotesis penelitian. Jika thitung > ttabel, maka Ho ditolak dan H1 diterima.

\section{HASIL DAN PEMBAHASAN}

Sebanyak 200 calon responden ditarik berdasarkan metode purposive sampling. Responden kemudian didata dan disajikan berdasarkan karakteristik-karakterisitk tertentu. Respon tinggi ditunjukkan dengan tingkat pengembalian sebesar 93\% atau sebanyak 177 orang. Dari 177 kuesioner yang terkunpul 12 diantaranya tidak bisa digunakan karena partisipan menjawab tidak jelas atau tidak lengkap sehingga rusak dan tidak bias dipakai dalam pengujian. Total 165 kuesioner dianggap layakuntuk disertakan dalam penelitian ini. Profil responden diklasifikasikan berdasarkan usia, gender, frekuensi pembelian dan tempat pembelian favorit.

\section{Profil Responden}

Sejumlah 165 partisipan dianggap eligible dalam penelitian ini. Tingkat kelayakan jumlah sampel diukur dengan menggunakan metode Kaizer-Meyer-Olkin. Semakin tinggi nilai KMO, maka semakin tinggi jumlah kelayakan sampel mewakili populasi. Dalam penelitian ini, karena menggunakan tingkat kepercayaan 95\%, maka rasio kecukupan sampel minimal sebesar 0,5. Dalam 
penelitian ini, diperoleh nilai KMO sebesar 0.794 yang berarti melampaui batas minimal kelayakan sampel. Dengan demikian penelitian ini dapat dilanjutkan karena jumlah sampel telah memenuhi syarat.

Tabel. 1 Rasio Kecukupan Sampel

\begin{tabular}{lrr}
\hline & KMO and Bartlett's Test \\
\hline Kaiser-Meyer-Olkin Measure of Sampling Adequacy. &, 794 \\
Bartlett's Test of Sphericity & Approx. Chi-Square & 2183,939 \\
& $\mathrm{df}$ & 136 \\
& Sig. &, 000 \\
\hline
\end{tabular}

Profil responden dideskripsikan berdasarkan usia, gender, dan frekuensi pembelian. Tabel 2 berikut ini menunjukkan sebaran profil responden berdasarkan karakteristik:

Tabel. 2 Karakterstik Demografi Responden

\begin{tabular}{|c|c|c|c|c|c|}
\hline \multirow{2}{*}{\multicolumn{2}{|c|}{ Demografi }} & \multicolumn{2}{|c|}{ Responden (165) } & \multirow{2}{*}{ Mean } & \multirow{2}{*}{ Standard Deviasi } \\
\hline & & $\mathbf{N}$ & $\%$ & & \\
\hline \multirow{3}{*}{ Usia } & $<20$ & 21 & 12,7 & \multirow{3}{*}{21,30} & \multirow{3}{*}{1,344} \\
\hline & $20-22$ & 122 & 74,0 & & \\
\hline & $>22$ & 22 & 13,3 & & \\
\hline \multirow{2}{*}{ Gender } & Pria & 61 & 37 & \multirow{2}{*}{1,63} & \multirow{2}{*}{0,038} \\
\hline & Wanita & 104 & 63 & & \\
\hline \multirow{4}{*}{$\begin{array}{l}\text { Frekuensi } \\
\text { Pembelian }\end{array}$} & Sekali & 18 & 10,9 & \multirow{4}{*}{2,64} & \multirow{4}{*}{0,811} \\
\hline & Jarang & 43 & 26,1 & & \\
\hline & Kadang & 86 & 52,1 & & \\
\hline & Sering & 18 & 10,9 & & \\
\hline \multirow{3}{*}{ Venue } & CGV Velvet & 33 & 20 & \multirow{3}{*}{1,68} & \multirow{3}{*}{0,789} \\
\hline & Cinemax Gold & 46 & 27,9 & & \\
\hline & XXI Premiere & 86 & 52,1 & & \\
\hline
\end{tabular}

Berdasarkan tabel 2, sebaran responden menunjukkan remaja dengan usia rentang 20-22 tahun terbanyak dengan jumlah 122 responden atau 74\%, dan sisanya terbagi hampir sama banyak baik untuk remaja dibawah 20 tahun (21 orang atau 12,7\%) dan diatas 22 tahun (22 orang atau 13,3\%). Untuk sebaran gender, tercatat responden wanita 2 kali jauh lebih banyak dari pada responden pria sebanyak 104 orang (63\%) dibandingkan responden pria sebanyak 61 orang (37\%). Dari sisi frekuensi pembelian tiket bioskop kelas premium menunjukkan 86 orang responden mengaku kadang (52,1\%) dan sisanya 43 orang mengaku jarang (26,1\%), serta sekali dan sering sama-sama tercatat 18 orang (10,9\%). Untuk profil pilihan sinema terbanyak dalam pilihan responden adalah sinema XXI Premiere sebanyak 86 orang (52,1\%) diikuti oleh Cinemax Gold sebanyak 46 orang (27,9\%), dan CGV Velvet sebanyak 33 orang (20\%). Hal ini bias terjadi karena disebabkan lokasi XXI Premiere berada di salah satu mall terbesar di Kota Manado dengan lokasi di jantung kota bisnis, sementara CGV dan Cinemax berada di pinggiran kota yang jauh dari keramaian. 


\section{Pengujian Validitas dan Reliabilitas}

Pengujian validitas digunakan untuk mengukur sejauh mana instrumen atau parameter dapat mengukur variabel dengan jelas. Dalam penelitian ini digunakan pendekatan Discriminant Validity dengan metode Confirmatory Factor Analysis. Suatu indikator dikatakan valid jika melewati batas minimal 0.4 sedangkan nilai minimal Cronbach alpha untuk reliabilitas adalah 0.6.

Berdasarkan tabel 3, seluruh parameter memenuhi syarat dalam pengujian validitas dan reliabilitas. Untuk lebih jelas dapat dilihat pada tabel 2. Convergent validity diitilik dengan melihat kriteria sebagai berikut: 1) semua indikator memiliki faktor loading lebih dari 0.7 ; 2) nilai composite reliabilities berada diatas 0.80 ; dan 3 ) nilai average variance extracted (AVE) pada setiap konstruk > 0.50 .

Tabel 3 juga menunjukkan pengukuran reliabilitas dengan menggunakan composite reliability pada setiap konstruk berada diatas 0.6 dengan interval (0,867-0.951). Pengujian reliabilitas dengan menggunakan composite reliability sebagaimana anjuran Wertz et al, (1978). Hasil pengujian menunjukkan semua item reliabel.

Tabel 3. Hasil Pengujian Validitas \& Reliabilitas

\begin{tabular}{|c|c|c|c|c|c|}
\hline Variabel & $\begin{array}{c}\text { Item } \\
\text { Loading }\end{array}$ & $\begin{array}{l}\text { Composite } \\
\text { Reliability }\end{array}$ & Mean & $\begin{array}{l}\text { Standard } \\
\text { Deviation }\end{array}$ & Variance \\
\hline Prestise Merek & & 0.834 & & 5.232 & 27.384 \\
\hline Merek X merupakan gaya hidup terkini & 0.801 & & 5,897 & & \\
\hline Merek X memberikan prestise bagi pengguna & 0.862 & & 5,775 & & \\
\hline Merek X memberikan status sosial & 0.863 & & 5,400 & & \\
\hline Merek X menunjukkan kemakmuran & 0.895 & & 5,266 & & \\
\hline Kepercayaan Merek & & 0.938 & & 4.262 & 21.406 \\
\hline Saya percaya dengan merek $\mathrm{X}$ & 0.939 & & 6,151 & & \\
\hline Saya mengandalkan merek X & 0.927 & & 6,030 & & \\
\hline Merek X merupakan andalan saya & 0.936 & & 5,933 & & \\
\hline Merek X aman digunakan & 0.874 & & 6,048 & & \\
\hline Cinta Merek & & 0.890 & & 5,560 & 30,917 \\
\hline Saya menggunakan merek yang tepat & 0.782 & & 6,054 & & \\
\hline Merek X membuat saya nyaman & 0.927 & & 6,212 & & \\
\hline Merek X merek yang hebat & 0.797 & & 5,854 & & \\
\hline Saya menyukai merek $\mathrm{X}$ & 0.774 & & 6,163 & & \\
\hline Saya merasa terikat dengan merek $\mathrm{X}$ & 0.837 & & 4,987 & & \\
\hline Saya merasa puas dengan merek $\mathrm{X}$ & 0.796 & & 6,024 & & \\
\hline Harga Premium & & 0.938 & & 4.626 & 21.406 \\
\hline Meski lebih mahal, namun lebih baik & 0.851 & & 5,290 & & \\
\hline $\begin{array}{l}\text { Saya rela membayar lebih mahal untuk } \\
\text { produk ini }\end{array}$ & 0.942 & & 4,800 & & \\
\hline $\begin{array}{l}\text { Saya akan tetap menggunakan produk ini } \\
\text { meskiyang lain lebih murah }\end{array}$ & 0.851 & & 4,406 & & \\
\hline
\end{tabular}




\section{Uji Asumsi Klasik}

1. Uji Multikolinearitas

Pengujian multikolinearitas dilakukan dengan melihat seberapa besar nilai VIF pada pengujian linear. Apabila nilai VIF tidak lebih besar dari 10, maka data dapat dikatakan tidak terindikasi mulitkolinearitas. Dalam penelitian ini, setiap konstruk pengujian memilik nilai VIF dibawah 10, sehingga dengan demikian dapat disimpulkan data terbebas dari multikolinearitas. Untuk lebih jelasnya dapat dilihat pada tabel 4 dibawah ini.

Tabel 4. Pengujian Multikolinearitas

\begin{tabular}{|c|c|c|c|c|c|c|c|}
\hline \multirow[t]{2}{*}{ Model } & \multicolumn{2}{|c|}{$\begin{array}{l}\text { Unstandardized } \\
\text { Coefficients }\end{array}$} & \multirow{2}{*}{$\begin{array}{c}\text { Standardized } \\
\text { Coefficients } \\
\text { Beta } \\
\end{array}$} & \multirow[b]{2}{*}{$\mathrm{t}$} & \multirow[b]{2}{*}{ Sig. } & \multicolumn{2}{|c|}{ Collinearity Statistics } \\
\hline & B & Std. Error & & & & Tolerance & VIF \\
\hline (Constant) & 14,121 & 2,103 & & 6,715 & ,000 & & \\
\hline BrandPrestige & ,164 & ,049 & ,267 & 3,321 & 001 & 894 & 1,118 \\
\hline BrandLove & -071 & ,046 & -,124 & $-1,543$ & 125 & 898 & 1,114 \\
\hline BrandTrust &,- 031 & ,053 &,- 045 &,- 593 &, 554 & 993 & 1,007 \\
\hline
\end{tabular}

a. Dependent Variabel: PremiumPrice

Pengujian normalitas dilakukan dengan menggunakan metode Kolmogorov-Smirnov dimana nilai ambang batas terendah 0,05. Hasil pengujian menunjukkan nilai KS sebesar 0,076 dengan signifikansi 0,022. Dengan demikian dapat dipastikan data terdistribusi normal. Untuk lebih jelasnya dapat dilihat pada tabel 5 dibawah ini.

Tabel 5. Pengujian Multikolinearitas

\begin{tabular}{|c|c|c|}
\hline \multicolumn{3}{|c|}{ One-Sample Kolmogorov-Smirnov Test } \\
\hline & & Unstandardized Residual \\
\hline $\mathrm{N}$ & & 165 \\
\hline Normal Parameters ${ }^{\mathrm{a}, \mathrm{b}}$ & Mean & ,0000000 \\
\hline Most Extreme Differences & $\begin{array}{l}\text { Std. Deviation } \\
\text { Absolute }\end{array}$ & $\begin{array}{r}2,95977375 \\
, 076\end{array}$ \\
\hline Test Statistic & $\begin{array}{l}\text { Positive } \\
\text { Negative }\end{array}$ & $\begin{array}{r}, 052 \\
-, 076 \\
, 076\end{array}$ \\
\hline Asymp. Sig. (2-tailed) & &, $022^{\mathrm{c}}$ \\
\hline
\end{tabular}
a. Test distribution is Normal.
b. Calculated from data.
c. Lilliefors Significance Correction.

2. Uji Heterokedasitis

Pengujian heterokedasitis dapat dilakukan dengan melihat sebaran pola pada scatter plot. Apabila sebaran pola terbagi rata maka dapat dipastikan data terbebas dari unsur multikolinearitas. 


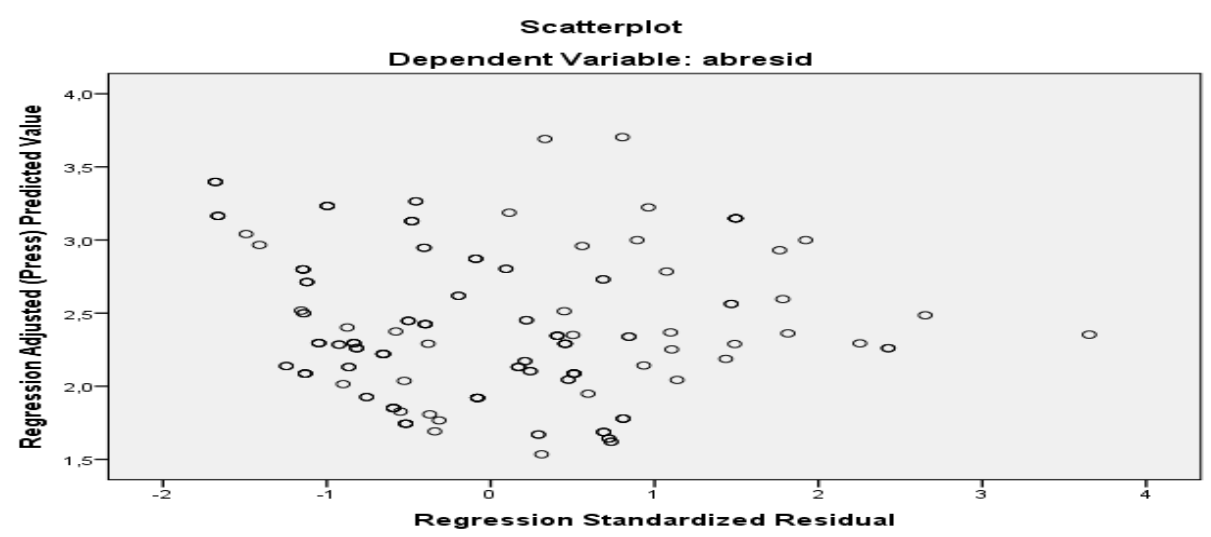

Gambar 2 Uji Heterokedasitis

\section{Pengujian Hipotesis dan Diskusi}

Pengujian hipotesis dilakukan untuk mengukur analisis korelasi antar konstruk. Tabel 3 menunjukkan arah hubungan antar konstruk dan hasil estimasi setiap hubungan yang dihopotesiskan dan tingkat signifikansinya.

Table 6. Analisa Koefisien

\begin{tabular}{clcccc}
\hline $\mathbf{H}$ & \multicolumn{1}{c}{ Path } & Coeff. & tvalue & p value & n.s \\
\hline H1 & Prestise Merek $\rightarrow$ Cinta Merek & 0.319 & 4.280 & .000 & sign \\
H2 & Kepercayaan Merek $\rightarrow$ Cinta Merek & 0.051 & .686 & .494 & n.sign \\
H3 & Prestise Merek $\rightarrow$ Harga Premium & 0.267 & 3.321 & .001 & sign \\
H4 & Kepercayaan Merek $\rightarrow$ Harga Premium & -0.045 & -0.593 & .554 & n.sign \\
H5 & Cinta Merek $\rightarrow$ Harga Premium & -0.124 & 1.543 & .125 & n.sign \\
\hline
\end{tabular}

Tabel 6 menunjukkan hubungan antar konstruk berdasarkan pengujian hipotesis. Penjelasan pada setiap hubungan akan dibahas dibawah ini:

1. Pengaruh prestise merek terhadap cinta merek dan harga premium

Tujuan dari pengujian hipotesis 1 adalah untuk mengukur hubungan antara prestise merek terhadap cinta merek dan harga premium. Hasil pengujian menunjukkan prestise merek mempengaruhi cinta merek secara positif signifikan (4.280). dengan demikian, H1 diterima.

Hasil penelitian menunjukkan setiap produk dengan tingkat prestise yang tinggi akan mendorong munculnya rasa cinta akan merek pada konsumen. Hal ini wajar terjadi karena produk dengan prestise yang tinggi akan memberikan kenyamanan dan status sosial yang lebih baik daripada menggunakan produk yang biasa-biasa saja. Pembelian produk dengan prestise tinggi memerlukan pengorbanan yang besar baik dari segi materi maupun emosional. Maka tidak mengherankan apabila produk dengan tingkat prestise tinggi akan memunculkan perasaan emosional bagi pemiliknya. Rasa bangga dan kemapanan yang dimiliki oleh penggunanya sebagai efek atas kepemilikan produk yang memiliki prestise.

Hasil mengejutkan pada pengujian antara prestise merek terhadap harga premium yang bernilai negatif meski tidak signifikan $(-1,543)$. Hasil ini jelas berbeda dengan penelitian 
sebelumnya yang umumnya berpendapat konsumen akan rela mengorbankan materi yang lebih besar untuk mendapatkan produk dengan prestise yang tinggi. Oleh karena itu, H2 ditolak.

Pengujian prestise merek pada harga premium berhubungan terbalik meski tidak signifikan. Dalam penelitian ini, prestise dianggap tidak akan mendorong konsumen untuk rela membayar lebih tinggi untuk mendapatkan merek tersebut. Untuk konsumen Indonesia pada umumnya, dan Kota Manado pada khususnya, konsumen bersifat rasional dan sensitif terhadap harga. Suatu merek yang memiliki prestise tinggi akan ditinggalkan jika menempatkan harga yang terlalu mahal. Konsumen akan memilih merek yang lain jika ditawarkan harga yang lebih murah, meskipun dengan risiko kehilangan prestise atas merek yang ditinggalkan. Hal ini menunjukkan konsumen usia muda yang terlibat dalam penelitian ini belum memiliki kemampuan untuk mengeksplorasi kemampuan finansial yang lebih tinggi dan beralih dari hedonis menuju utilitarian pada saat harga merek dengan prestise bertambah.

2. Pengaruh kepercayaan merek terhadap cinta merek dan harga premium

Dalam penelitian ini, pengujian hubungan kepercayaan merek terhadap cinta merek dan harga premium menunjukkan pengaruh yang tidak signifikan. Hal ini ditunjukkan dengan nilai uji t pada cinta merek $(0,686)$ dan harga premium $(-0,593)$. dengan demikian H3 dan H4 ditolak.

Hal ini menunjukkan kepercayaan merek bukan merupakan dasar terbentuknya cinta merek. Bagi produk hiburan seperti halnya sinema, konsumen mudah berpindah merek mengingat perbedaan jam tayang dan film tayangan. Oleh karena itu, cinta merek pada industri hiburan sinema sulit dijangkau.

Kejutan justru ditunjukkan atas hubungan antara kepercayaan merek dengan harga premium. Hasil penelitian justru menunjukkan merek yang dipercayai akan menuurunkan kesediaan membeli pada harga yang tinggi. Hal ini memungkin terjadi karena dalam penelitian ini, responden adalah konsumen muda usia 17-22 tahun dimana harga merupaka isu utama bagi mereka. Kelompok umur muda usia sangat sensitifterhadap harga sehingga apabila terjadi kenaikan harga, maka mudah bagi mereka berpindah. Hal yang sama berlaku apabila sinema tertentu memberikan promo ataupun benefit lainnya.

3. Pengaruh cinta merek terhadap harga premium

Hasil pengujian pengaruh cinta merek terhadap harga premium negatif meski tidak signifikan(-1.543). Hal ini menunjukkan meskipun konsumen memiliki rasa cinta terhadap suatu merek, namun apabila merek tersebut ditawarkan pada harga tinggi, maka probabilitas konsumen untuk meninggalkan merek tersebut membesar. Dengan demikian H5 ditolak.

Hasil penelitian ini sejalan dengan temuan Rodrigues and Reis, (2013). Dalam penelitian ini, kelompok umur responden yang masih muda menjadi titik perhatian akan pertumbuhan rasa cinta pada merek. Usia muda merupakan usia yang tidak stabil. Konsumen pada usia ini suka mencoba hal-hal baru, berpetualang, lebih bebas dalam menentukan pilihan, ekstrovert, dan berani tampil independen. Kecintaan pada merek akan mudah sirna apabila harga menjadi isu dalam 
pengambilan keputusan. Dalam keterbatasan budget, maka keputusan rasional dalam memilih merek menjadi lebih penting dibanding keputusan emosional karena kebiasaan penggunaan.

\section{Temuan Lainnya}

Meski dalam penelitian ini, peran moderasi tidak menjadi titik perhatian dan tujuan penelitian, namun kemungkinan adanya peran tersebut dari salah satu variabel tidak dapat dipungkiri. Dalam penelitian ini, baik hubungan antara prestise merek dan cinta merek, maupun cinta merek dengan harga premium telah diketahui signifikan. Sementara itu, hubungan antara kepercayaan merek dengan cinta merek tidak signifikan.

Tabel 7. Analisa Koefisien dengan Efek Moderasi

\begin{tabular}{lcccc}
\hline \multicolumn{1}{c}{ Path } & Coeff. & 'value & p value & n.s \\
\hline Prestise Merek $\rightarrow$ Harga Premium & -1.239 & -2.152 & .033 & n.sign \\
Kepercayaan Merek $\rightarrow$ Harga Premium & 1.186 & 2.254 & .026 & sign \\
Cinta Merek $\rightarrow$ Harga Premium & -0.080 & -0.127 & .899 & n.sign \\
Prestise Merek XCinta Merek & 2.144 & -2.681 & .008 & sign \\
Kepercayaan Merek X Cinta Merek & -1.708 & -2.434 & .016 & n.sign \\
\hline
\end{tabular}

Berdasarkan tabel 7 diperoleh nilai akhir koefisien untuk pengujian efek moderasi dari variabel cinta merek. Dalam penelitian ini, efek moderasi dikhususkan pada kedua variabel antseden, yakni prestise merek dan kepercayaan merek. Pada variabel prestise merek, ditemukan pengaruh kepada harga premium tidak signifikan. Namun setelah diberikan efek moderasi dari cinta merek, berubah menjadi signifikan. Dengan demikian, cinta merek telah menjalankan efek moderasi secara murni. Sebaliknya, pada variabel kepercayaan merek ditemukan hubungan non signifikan dengan harga premium baik sebelum ada efek moderi maupun sesudah efek moderasi. Hasil ini menunjukkan cinta merek berperan sebagai homologiser moderator (moderator potensial). Dengan demikian hubungan kausal yang terjadi pada penelitian ini dapat digambarkan sebagai berikut.

\section{Pengujian Model Fit}

Untuk menguji kesahihan model penelitian, digunakan nilai $\mathrm{R}^{2}$ dengan membandingkan nilai tersebut sebelum dan sesudah efek moderasi dari cinta merek diberikan.

Tabel 8. Nilai $\mathbf{R}^{2}$

\begin{tabular}{rrrrr}
\hline \multicolumn{1}{l}{ Model } & R & R Square & Adjusted R Square & Std. Error of the Estimate \\
\hline 1 & .264 & .070 & .052 & 3.12052 \\
2 & .384 & .147 & .121 & 3.00595 \\
\hline
\end{tabular}

Berdasarkan tabel 8 ditemukan sejumlah perubahan yang signifikan. Nilai koefisien regresi sebelum moderasi sebesar 0,264 meningkat setelah diberikan efek moderasi sebesar 0,384 yang menunjukkan besaran pengaruh variabel independen yang dimoderasi terhadap harga premium. Nilai koefisien determinasi meningkat dari 0,070 menjadi 0,147. Hal ini menunjukkan kontribusi prestise 
merek dan kepercayaan merek setelah efek moderasi cinta merek pada harga premium. Dengan demikian, peran cinta merek sebagai efek moderasi menunjukkan model fit yang lebih baik.

\section{KESIMPULAN}

Dari lima hipotesis yang dibangun dalam penelitian ini, hasil pengujian menunjukkan 3 (tiga) hipotesis ditolak dan 2 (dua) lainnya diterima. Hasil penelitian menunjukkan prestise merek memberikan efek positif dalam terbentuknya cinta merek. Hal ini menunjukkan kemampuan prestise merek sebagai predictor yang baik bagi cinta merek. Selain itu, prestise juga mampu memprediksi harga premium secara signifikan. Meskipun dalam penelitian ini hubungan kepercayaan merek dengan cinta merek tidak signifikan, namun arah penelitian menunjukkan efek positif. Hal yang sama berlaku pada hubungan kepercayaan merek dengan harga premium. Pada hubungan yang kedua, signifikansi justru terjadi seandainya efek cinta merek dihilangkan.

Temuan baru dalam penelitian ini adalah ini adalah adanya peran moderasi dari cinta merek baik sebagai moderator murni antara prestise merek dengan harga premium maupun moderator homologiser antara kepercayaan merek dengan harga premium. Oleh karena itu, cinta merek memiliki peran vital dalam membangun hubungan antara prestise merek dan kerelaan konsumen untuk berkorban lebih banyak.

\section{Implikasi Manajerial}

Pada penelitian ini, pengujian hipotesis menunjukkan signifikansi pada pengaruh prestise merek terhadap cinta merek dan pengaruh cinta merek terhadap harga premium. Dengan demikian perusahaan seyogyanya meningkatkn nilai prestise produk dan layanan yang ditawarkan kepada konsumen. Produk dan layanan yang memiliki prestise akan meningkatkan status sosial dan kelas yang berbeda bagi individu. Bagi individu yang sudah merasaan manfaat dari nilai prestisius produk dan layanan, perlahan akan menimbulkan rasa cinta pada merek yang bersangkutan.

Disisi lain, membangun merek yang prestisius terbukti tidak akan menurunkan minat beli jika harga jualnya meningkat. Konsumen telah menyadari sepenuhnya bahwa sebuah produk dan layanan yang prestisius tentu saja berimbang dengan harga yang dibebankan. Oleh karena itu, pelaku usaha seyogyanya memahami segmen yang tepat bagi produk dan layanan yang prestisius sehingga harga premium yang ditawar tidak akan menjadi kendala. Adanya peran cinta merek sebagai moderasi juga menunjukkan pentingnya variabel ini dalam menunjang keseimbangan prestise merek dengan harga premium. Hal ini sebagai penguat alasan kerelaan konsumen untuk membayar harga premium untuk mendapatkan produk dan layanan yang prestisius.

\section{Saran}

Terlepas dari temuan-temuan tersebut, penelitian ini masih tesirat sejumlah kekurangan sehingga belum bisa digeneralisir. Pertama, sampel yang digunakan hanya kelompok sampel anak 
muda dibawah usia 25 tahun. Tentu saja kelompok sampel ini belum menggambarkan keseluruhan populasi kelompok umur yang ada. Kedua, industri hiburan sinema merupakan industri dengan karaktersitik yang berbeda dengan industri lain. Industri sinema dengan kelas premium hanya memiliki 3 (tiga) pemain dalam pasar sehingga provider cukup bebas memainkan peran sentral. Ketiga, untuk penelitian lebih lanjut, dalam penelitian ini telah memenuhi syarat pengujian peran cinta merek sebagai mediator namun belum terlaksana. Keempat, untuk memenuhi unsur penelitian yang kompleks dan komprehensif, kami menganjurkan penambahan beberapa anteseden cinta merek seperti citra merek, nama merek, dan atau program loyalitas termasuk penggunaan uang elektronik dalam transaksi serta variabel konsekuensi seperti, komitmen pada merek, perilaku beralih, persepsi kualitas dan nilai serta kepuasan.

\section{REFERENSI}

Aaker, D. A. 1991. Managing Brand Equity. Free Pass (Vol. 56). New York: Innova. https://doi.org/10.2307/1252048

Albert, N., dan Merunka, D. 2013. The Role of Brand Love in Consumer-Brand Relationships. Journal of Consumer Marketing, 30 (3), 258-267. https://doi.org/10.1108/07363761311328928

Albert, N., Merunka, D., dan Valette-florence, P. 2008. When Consumers Love their Brands: Exploring the Concept and its Dimensions. Journal of Business Research, 61, 1062-1075. https://doi.org/10.1016/j.jbusres.2007.09.014

Bearden, W. O., dan Etzel, M. J. 1982. Reference Group Influence on Product and Brand Purchase Decisions. Journal of Consumer Research, 9 (2), 183. https://doi.org/10.1086/208911

Belén del Rio, A., Vázquez, R., dan Iglesias, V. 2001. The Effects of Brand Associations on Consumer. Journal of Consumer Marketing, 18(5), 410-425. https://doi.org/10.1108/07363760110398808

Belk, R. W. 2004. Men and their Machines. Advances in Consumer Research, 31, 273-278.

Belk, R. W., Ger, G., dan Askegaard, S. 2003. The Dire of Desire: A multisited Inquiry Into Consumer Passion. Journal of Consumer Research, 30 (December), 326-357. https://doi.org/10.2139/ssm.354640

Bizman, A., dan Yinon, Y. 2002. Engaging in Distancing Tactics Among Sport Fans: Effects on SelfEsteem and Emotional Responses. The Journal of Social Psychology, 142(3), 381-392. https://doi.org/10.1080/00224540209603906

Carlson, B. D., Donavan, D. T., dan Cumiskey, K. J. 2009. Consumer-Brand Relationships in Sport: Brand Personality and Identification. International Journal of Retail and Distribution Management, 37 (4), 370-384. https://doi.org/10.1108/09590550910948592

Carroll, B. A., dan Ahuvia, A. C. 2006. Some Antecedents and Outcomes of Brand Love. Marketing Letters, 17 (2), 79-89. https://doi.org/10.1007/s11002-006-4219-2

Chinomona, R. 2013. The Influence of Brand Experience on Brand Satisfaction, Trust and Attachment in South Africa. International Business and Economics Research Journal, 12(10), 1303-1316. https://doi.org/10.19030/iber.v12i10.8138

Chiu, C.-M., Huang, H.-Y., dan Yen, C.-H. 2010. Antecedents of Trust in Online Auctions. Electronic $\begin{array}{lllll}\text { Commerce Research and Applications, } 9 & \text { (2), 148-159. }\end{array}$ https://doi.org/https://doi.org/10.1016/j.elerap.2009.04.003

Delgado-Ballester, E., dan Munuera-Alemán, J. L. 2001. Brand Trust in the Context of Consumer Loyalty. European Journal of Marketing, 35(11/12), 1238-1258. https://doi.org/10.1108/EUM0000000006475

Dubois, B., dan Czellar, S. 2002. Report Prestige Brands or Luxury Brands? An Exploratory Inquiry on Consumer Perceptions. In Marketing in a Changing World: Scope, Opportunities and Challenges: Proceedings of the 31st EMAC Conference (pp. 1-10). University of Minho, Portugal. 
Erciş, A., Ünal, S., Candan, F. B., dan Yıldırım, H. 2012. The Effect of Brand Satisfaction, Trust and Brand Commitment on Loyalty and Repurchase Intentions. Procedia-Social and Behavioral Sciences, 58, 1395-1404. https://doi.org/10.1016/j.sbspro.2012.09.1124

Erdoğmuş, I., dan Büdeyri-Turan, I. 2012. The Role of Personality Congruence, Perceived Quality and Prestige on Ready-to-Wear Brand Loyalty. Journal of Fashion Marketing and Management, 16(4), 399-417. https://doi.org/10.1108/13612021211265818

Fournier, S. 1998. Consumers and Their Brands: Developing Relationship Theory in Consumer Research. Journal of Consumer Research, 24(4), 343-353. https://doi.org/10.1086/209515

Ganesan, S. 1994. Determinants of Long-Term Orientation in Buyer-Seller Relationships. Journal of Marketing, 58(2), 1-19. https://doi.org/10.2307/1252265

Hanzaee, K. H., dan Andervazh, L. 2012. An Analysis of some Moderating Variables on the Value, Brand Trust and Brand Loyalty Chain. Research Journal of Applied Sciences, Engineering and Technology, 4 (10), 1403-1413.

Hess, J. S., Singh, J., Metcalf, L. E., dan Danes, J. 2014. The Impact of Consumer Product Package Quality on Consumption Satisfaction, Brand Perceptions, Consumer Investment and Behavior. Journal of Applied Packaging Research, 6(1), 23-41. https://doi.org/10.14448/japr.01.0003

Hwang, J., dan Han, H. 2001. Examining Strategies for Maximizing and Utilizing Brand Prestige in the Luxury Cruise Industry. Tourism Management, 40, 244-259. https://doi.org/https://doi.org/10.1016/j.tourman.2013.06.007

Jin, N. P, Line, N. D., dan Merkebu, J. 2016. The Impact of Brand Prestige on Trust, Perceived Risk, Satisfaction, and Loyalty in Upscale Restaurants. Journal of Hospitality Marketing and Management, 25(5), 523-546. https://doi.org/10.1080/19368623.2015.1063469

Kwak, L. E., dan Sojka, J. Z. 2010. If they could see me now: Immigrants' use of Prestige Brands to Convey Status. Journal of Consumer Marketing, 27(4), 371-380. https://doi.org/10.1108/07363761011052404

Louis, D., dan Lombart, C. 2010. Impact of Brand Personality on three Major Relational Consequences (Trust, Attachment and Commitment to the Brand): Case Study of Nestle Nutrition Company in Tehran, Iran. Journal of Product and Brand Management, 19(2), 114-130. https://doi.org/10.1108/10610421011033467

Molinari, L. K., Abratt, R., dan Dion, P. 2008. Satisfaction, Quality and Value and Effects on Repurchase and Positive Word-of-Mouth Behavioral Intentions in a B2B Services Context. Journal of Services Marketing, 22(5), 363-373. https://doi.org/10.1108/08876040810889139

Morgan, R. M., dan Hunt, S. D. 1994. The Commitment-Trust: Theory of Relationship Marketing. Journal of Marketing, 58(July), 20-38. https://doi.org/10.1177/002224299405800302

Netemeyer, R. G., Krishnan, B., Pullig, C., Wang, G., Yagci, M., Dean, D.,dan Wirth, F. 2004. Developing and Validating Measures of Facets of Customer-Based Brand Equity. Journal of Business Research, 57(2), 209-224. https://doi.org/10.1016/S0148-2963(01)00303-4

Pandowo, A. 2017. Creating Brand Commitment As an Outcome of Brand Prestige, Brand Familiarity and Brand Passion the Evidence of Young Costumers in Franchise Restaurant. International Journal of Business Marketing and Management, 2(11), 20-27.

Phau, I., dan Prendergast, G. 2000. Conceptualizing the Country of Origin of Brand. Journal of Marketing Communications, 6(3), 159-170. https://doi.org/10.1080/13527260050118658

Prince, M., dan Davies, M. A. 2009. A Latent Class Analysis of Brand Prestige. Model Assisted Statistics and Applications, 4(3), 171-180. https://doi.org/10.3233/MAS-2009-0122

Pritchard, M. P., Havitz, M. E., dan Howard, D. R. 1999. Analyzing the Commitment-Loyalty Link in Service Contexts. Journal of the Academy of Marketing Science, 27(3), 333-348. https://doi.org/10.1177/0092070399273004

Rodrigues, P., dan Reis, R. 2013. The influence of "Brand Love" in Consumer Behavior - The Case of Zara and Modalfa Brands. In Proceedings of 22nd International Business Research Conference (pp. 1-9).

Schau, H. J., Muñiz Jr, A. M., dan Arnould, E. J. 2009. How Brand Community Practices Create Value. Journal of Marketing, 73(September), 30-51. https://doi.org/10.1509/jmkg.73.5.30

Sharma, N., dan Patterson, P. G. 2000. Switching Costs, Alternative Attractiveness and Experience as Moderators of Relationship Commitment in Professional, Consumer Services. International 


$$
\text { Journal of Service Industry Management, 11(5), 470-490. }
$$
https://doi.org/10.1108/09564230010360182

Steenkamp, J.-B. E. M., Batra, R., dan Alden, D. L. 2003. How Perceived Brand Globalness Creates Brand Value. Journal of International Business Studies, 34(1), 53-65. https://doi.org/10.1057/palgrave.jibs.8400002

Suh, B., dan Han, I. 2003. The Impact of Customer Trust and Perception of Security Control on the Acceptance of Electronic Commerce. International Journal of Electronic Commerce, 7(3), 135-161. https://doi.org/10.1080/10864415.2003.11044270

Sutikno, B. 2011. Does Consumers' Brand Identification Matter: The Mediating Roles of Brand Loyalty. International Journal of Interdisciplinary Social Sciences, 6(3), 319-331. https://doi.org/10.18848/1833-1882/CGP/v06i03/51695

Thomson, M., MacInnis, D. J., dan Park, C. W. 2005. The Ties That Bind: Measuring the Strength of Consumers' Emotional Attachments to Brands. Journal of Consumer Psychology, 15(1), 77-91. https://doi.org/https://doi.org/10.1207/s15327663jcp1501 10

Truong, Y., McColl, R., dan Kitchen, P. J. 2009. New Luxury Brand Positioning and the Emergence of Masstige Brands. Journal of Brand Management, 16(5-6), 375-382. https://doi.org/10.1057/bm.2009.1

Vigneron, F., dan Johnson, L. W. 1999. A Review and a Conceptual Framework of Prestige-Seeking Consumer Behavior. Academy of Marketing Science, 1999(1), 1-17.

Yasin, M. 2013. Brand Love: Mediating Role in Purchase Intentions and Word-of Mouth. IOSR Journal of Business and Management, 7(2), 101-109. https://doi.org/10.9790/487x-072101109 